\title{
Impact of obesity on breast cancer, endometrial cancer, fertility and complications in pregnancy
}

\author{
Hans-Christian Kolberg* \\ Department of Gynecology and Obstetrics, Marienhospital Bottrop gGmbH, Josef-Albers-Str. 70, 46236 Bottrop, Germany
}

\begin{abstract}
Obesity is a well-known risk factor for breast cancer and endometrial cancer. It also increases the risk for a poor outcome of desiderum infantum and the risk for complications in pregnancy. Weight reduction can reduce the increased risk again. Obese women should be strongly encouraged to reduce their BMI and should be educated about the detrimental effects of obesity by their physicians. Whereas physical activity and healthy nutrition are the most important factors in obtaining a normal bodyweight, not every woman will reach a BMI reducing her risk for the conditions mentioned above. In these cases bariatric surgery is a potential management option.
\end{abstract}

\section{Introduction}

Obesity is a well known risk factor for the development of cardiac and endocrine disorders. But the consequences of obesity are not limited to internal medicine, they are evident in almost every field of medicine. Especially the endocrine consequences have an impact on the field of gynecology and obstetrics. We took a look at the published data concerning breast cancer, endometrial cancer, fertility and pregnancy.

\section{Breast cancer}

Whereas obesity reduces the risk to develop a premenopausal breast cancer [1-3], it increases the risk to develop a postmenopausal breast cancer [1-4]. About $25 \%$ of breast cancer cases after menopause are caused by obesity $[1,2]$. A weight gain of only $10 \mathrm{~kg}$ between the age of 18 and menopause increases the risk for a postmenopausal breast cancer by $16 \%[5,6]$. A BMI over 25 increases the breast cancer risk proportionally. Per 5 BMI-units this increase lies within the range of $12-20 \%[1-4]$. But obesity does not only increase the risk of developing breast cancer, it also is correlated with a shorter overall survival in patients who are diagnosed with the disease [7]. A BMI higher than 27 triples the risk of a breast cancer patient to die because of the disease $[8,9]$. The main reason for the increased risk of obese women to develop breast cancer and to die from it is the production of estrogen and growth factors in fat tissue, especially in abdominal fat [10]. The reduction of body weight leads to a decrease of the risk for breast cancer [11].

\section{Endometrial cancer}

Obesity is a well-known risk factor for endometrial cancer, with a direct link between bodyweight and the risk of developing the disease [1]. The fact of being obese increases the risk of a woman for endometrial cancer by the factor two to three $[12,13]$. An overweight of 50 pounds increases the risk by the factor 10 [14]. And whereas endometrial cancer is a curable disease the risk of dying of it is also increased for obese women $[15,16]$. The explanation for the increased risk for endometrial cancer is the "unopposed estrogen hypothesis", based on the knowledge that the increased estrogen and androgen levels as well as the resulting hyperinsulinaemia in obese women lead to mitogenous effects on the endometrium especially after menopause, when they are no longer opposed by progestin [17]. Weight loss reduces the cancer risk in obese women $[18,19]$. There are first data that weight loss after bariatric surgery may reduce the risk for endometrial cancer by as much as $70 \%$, if the women do not put on weight again [20].

\section{Fertility}

Obesity has a detrimental effect on female fertility [21]. Whereas the relative risk of infertility because of anovulatory cycles is 2.7 in women whose BMI is higher than 32 at the age of 18 [22], even in women who are having ovulatory cycles the chance of conception is decreased by $5 \%$ for every increase of the BMI by one unit [23]. The reasons for this decrease in fertility are multivariate, including higher leptin and lower adiponectin levels, thus influencing the expression of steroids in the ovaries and increasing the insulin levels resulting in a hyperandrogenaemia by inhibiting the sex hormone binding globulin production in the liver $[23,24]$. Another reason for reduced fertility is the higher incidence of the polycystic ovary syndrome in obese women [25]. Weight loss in women with polycystic ovary syndrome, obtained by lifestyle therapy, pharmacological therapy or bariatric surgery, improves spontaneous ovulation and pregnancy rates [25]. Since weight loss prior to conception improves live birth rates in obese women with or without polycystic ovary syndrome, it has to be considered the first line therapy for infertility in obese women [26].

\section{Complications in pregnancy}

Obesity increases the risk of pregnant women for suffering of

Correspondence to: Hans-Christian Kolberg, Department of Gynecology and Obstetrics, Marienhospital Bottrop gGmbH, Josef-Albers-Str. 70, 46236 Bottrop, Germany, E-mail: hans-christian.kolberg@mhb-bottrop.de

Key words: obesity, breast cancer, endometrial cancer, fertility, pregnancy complications Received: September 06, 2015; Accepted: September 22, 2015; Published: September 25, 2015 
complications in pregnancy, such as preeclampsia, hypertension, gestational diabetes and delivery by cesarean section [27-30]. But not only is the pregnant woman herself at risk. Children of obese pregnant women are at a higher risk for stillbirth, prematurity, congenital abnormalities, macrosomia and obesity in childhood [31,32]. With a BMI between 30 and 39.9 the relative risk for gestational diabetes is up to 4,0 , the relative risk for gestational hypertension up to 3,2 and the risk for preeclampsia up to 3,3, in relation to the BMI [30]. Therefore preconception assessment of and counseling on obesity are highly encouraged [33]. If a normal body weight cannot be obtained by conservative treatment, bariatric surgery can be considered. After bariatric surgery pregnancy complications like gestational diabetes, preeclampsia, gestational hypertension and macrosomia are less likely to occur $[34,35]$.

\section{Conclusion}

Obesity in women increases the risk of developing breast cancer and endometrial cancer, being infertile and suffering from complications in pregnancy. Obese women should be strongly encouraged to reduce their BMI and should be educated about the detrimental effects of obesity by their physicians. Whereas physical activity and healthy nutrition are the most important factors in obtaining a normal bodyweight, not every woman will reach a BMI reducing her risk for the conditions mentioned above. In these cases bariatric surgery is a potential management option.

\section{Financial disclosures}

HCK received honoraria from Novartis, GSK, Pfizer, Carl Zeiss meditec, Roche, TEVA, Theraclion, Genomic Health, Amgen, Janssen and LIV Pharma.

\section{References}

1. Reeves GK, Pirie K, Beral V, Green J, Spencer E, et al. (2007) Cancer incidence and mortality in relation to body mass index in the Million Women Study: cohort study. BMJ 335: 1134. [Crossref]

2. Renehan AG, Tyson M, Egger M, Heller RF, Zwahlen M (2008) Body-mass index and incidence of cancer: a systematic review and meta-analysis of prospective observational studies. Lancet 371: 569-578. [Crossref]

3. Renehan AG, Soerjomataram I, Tyson M, Egger M, Zwahlen M, etal. (2010) Incident cancer burden attributable to excess body mass index in 30 European countries. Int $J$ Cancer 126: 692-702. [Crossref]

4. Deutsche Adipositas-Gesellschaft (DAG e.V., Deutsche Diabetes Gesellschaft (DDG), Deutsche Gesellschaft für Ernährung (DGE) e.V. \& Deutsche Gesellschaft für Ernährungsmedizin (DGEM) e.V. (2013) Interdisziplinäre Leitlinie der Qualität S3 zur, Prävention und Therapie der Adipositas“.

5. Eliassen AH, Colditz GA, Rosner B, Willett WC, Hankinson SE (2006) Adult weight change and risk of postmenopausal breast cancer. JAMA 296: 193-201. [Crossref]

6. Lahmann PH, Lissner L, Gullberg B, Olsson H, Berglund G (2003) A prospective study of adiposity and postmenopausal breast cancer risk: the Malmö Diet and Cancer Study. Int $J$ Cancer 103: 246-252. [Crossref]

7. Chang SH, Pollack LM, Colditz GA (2013) Obesity, mortality, and life years lost associated with breast cancer in nonsmoking US Women, National Health Interview Survey, 1997-2000. Prev Chronic Dis 10: E186. [Crossref]

8. Minicozzi P, Berrino F, Sebastiani F, Falcini F, Vattiato R, et al. (2013) High fasting blood glucose and obesity significantly and independently increase risk of breast cancer death in hormone receptor-positive disease. Eur J Cancer 49: 3881-3888. [Crossref]

9. Petrelli JM, Calle EE, Rodriguez C, Thun MJ (2002) Body mass index, height, and postmenopausal breast cancer mortality in a prospective cohort of US women. Cancer Causes Control 13: 325-332. [Crossref]

10. Howell A, Sims AH, Ong KR, Harvie MN, Evans DG, et al. (2005) Mechanisms of Disease: prediction and prevention of breast cancer--cellular and molecular interactions. Nat Clin Pract Oncol 2: 635-646. [Crossref]
11. Harvie M, Howell A, Vierkant RA, Kumar N, Cerhan JR, et al. (2005) Association of gain and loss of weight before and after menopause with risk of postmenopausal breast cancer in the Iowa women's health study. Cancer Epidemiol Biomarkers Prev 14: 656-661. [Crossref]

12. Havrilesky LJ, Maxwell GL, Myers ER (2009) Cost-effectiveness analysis of annual screening strategies for endometrial cancer. Am J Obstet Gynecol 200: 640.e1-8. [Crossref]

13. Kwon JS, Lu KH (2008) Cost-effectiveness analysis of endometrial cancer prevention strategies for obese women. Obstet Gynecol 112(1): 56-63. [Crossref]

14. Rose PG (1996) Endometrial carcinoma. N Engl J Med 335: 640-649. [Crossref]

15. von Gruenigen VE, Tian C, Frasure H, Waggoner S, Keys H, et al. (2006) Treatment effects, disease recurrence, and survival in obese women with early endometrial carcinoma : a Gynecologic Oncology Group study. Cancer 107: 2786-2791. [Crossref]

16. Arem H, Park Y, Pelser C, Ballard-Barbash R, Irwin ML, et al. (2013) Prediagnosis body mass index, physical activity, and mortality in endometrial cancer patients. $J$ Natl Cancer Inst 105: 342-349. [Crossref]

17. Kaaks R, Lukanova A, Kurzer MS (2002) Obesity, endogenous hormones, and endometrial cancer risk: a synthetic review. Cancer Epidemiol Biomarkers Prev 11: 1531-1543. [Crossref]

18. McCawley GM, Ferriss JS, Geffel D, Northup CJ, Modesitt SC (2009) Cancer in obese women: potential protective impact of bariatric surgery. J Am Coll Surg 208: 10931098. [Crossref]

19. Adams TD, Stroup AM, Gress RE, Adams KF, Calle EE, et al. (2009) Cancer incidence and mortality after gastric bypass surgery. Obesity (Silver Spring) 17: 796802. [Crossref]

20. Ward KK, Roncancio AM, Shah NR, Davis MA, Saenz CC, et al. (2014) Bariatric surgery decreases the risk of uterine malignancy. Gynecol Oncol 133: 63-66. [Crossref]

21. Pandey S, Pandey S, Maheshwari A, Bhattacharya S (2010) The impact of female obesity on the outcome of fertility treatment. J Hum Reprod Sci 3: 62-67. [Crossref]

22. Rich-Edwards JW, Goldman MB, Willett WC, Hunter DJ, Stampfer MJ, et al. (1194) Adolescent body mass index and infertility caused by ovulatory disorder. Am J Obstet Gynecol 171: 171-177. [Crossref]

23. van der Steeg JW, Steures P, Eijkemans MJ, Habbema JD, Hompes PG, et al. (2008) Obesity affects spontaneous pregnancy chances in subfertile, ovulatory women. Hum Reprod 23: 324-328. [Crossref]

24. Metwally M, Li TC, Ledger WL (2007) The impact of obesity on female reproductive function. Obes Rev 8: 515-523. [Crossref]

25. Gil-Campos M, Cañete RR, Gil A (2004) Adiponectin, the missing link in insulin resistance and obesity. Clin Nutr 23: 963-974. [Crossref]

26. Motta AB (2012) The role of obesity in the development of polycystic ovary syndrome Curr Pharm Des 18: 2482-2491. [Crossref]

27. Baeten JM, Bukusi EA, Lambe M (2001) Pregnancy complications and outcomes among overweight and obese nulliparous women. Am J Public Health 91: 436-440. [Crossref]

28. Cedergren MI (2004) Maternal morbid obesity and the risk of adverse pregnancy outcome. Obstet Gynecol 103: 219-224. [Crossref]

29. Sebire NJ, Jolly M, Harris JP, Wadsworth J, Joffe M, et al. (2001) Maternal obesity and pregnancy outcome: a study of 287,213 pregnancies in London. Int J Obes Relat Metab Disord 25: 1175-1182. [Crossref]

30. Weiss JL, Malone FD, Emig D, Ball RH, Nyberg DA, et al. (2004) Obesity, obstetric complications and cesarean delivery rate--a population-based screening study. $\mathrm{Am} \mathrm{J}$ Obstet Gynecol 190: 1091-1097. [Crossref]

31. Stothard KJ, Tennant PW, Bell R, Rankin J (2009) Maternal overweight and obesity and the risk of congenital anomalies: a systematic review and meta-analysis. JAMA 301: 636-650. [Crossref]

32. Oken E, Taveras EM, Kleinman KP, Rich-Edwards JW, Gillman MW (2007) Gestational weight gain and child adiposity at age 3 years. Am J Obstet Gynecol 196 322.e1-8. [Crossref]

33. American College of Obstetricians and Gynecologists (2013) ACOG Committee opinion no. 549: obesity in pregnancy. Obstet Gynecol 121: 213-217. [Crossref] 
Kolberg HC (2015) Impact of obesity on breast cancer, endometrial cancer, fertility and complications in pregnancy

34. Sheiner E, Levy A, Silverberg D, Menes TS, Levy I, et al. (2004) Pregnancy after bariatric surgery is not associated with adverse perinatal outcome. Am J Obstet Gynecol 190: 1335-1340. [Crossref]
35. Martin LF, Finigan KM, Nolan TE (2000) Pregnancy after adjustable gastric banding. Obstet Gynecol 95: 927-930. [Crossref]

Copyright: $(02015$ Kolberg HC. This is an open-access article distributed under the terms of the Creative Commons Attribution License, which permits unrestricted use, distribution, and reproduction in any medium, provided the original author and source are credited. 